\section{EUROPEAN SAFER URBAN MOTORCYCLING (ESUM) PROJECT: BENEFITS FROM MOBILITY ADVANTAGES PERTAINING TO REDUCTION OF INJURIES AMONG POWERED TWO WHEELERS IN URBAN AREAS}

doi:10.1136/injuryprev-2012-040590s.20

${ }^{1}$ E Petridou, ${ }^{1} E$ Germeni, ${ }^{2} V$ Vassileva, ${ }^{3} \mathrm{M}$ Pierini. ${ }^{1}$ Centre for Research \& Prevention of Injuries (CEREPRI), University of Athens, Greece; ${ }^{2}$ The Association of the European Motorcycle Industry (ACEM), Belgium; ${ }^{3}$ University of Florence, Italy

Background Powered Two Wheelers (PTWs) use has increased by an amazing $34 \%$ in the last decade in European cities, exceeding that of any other transport mode. PTWs, tailored for urban mobility, are cheaper, cleaner and more flexible transport means. Yet, compared to other modes of transport, PTWs have shown a slower rate of safety improvement.

Aims/Objectives/Purposes The project represents a collaborative venture involving four principal motorcycling cities (Barcelona, Paris, London and Rome), the PTW industry and academic/research organisations aiming to show that reduction in PTW collisions/casualties is feasible, provided user behaviour, vehicle design and road infrastructure are tackled.

Results/Outcome The readily applicable tools (www.esum.eu) include (a) MAIDS Urban Accident Report, (b) Good Practice Guide, examples of $>200$ projects (c) Action Pack-simple methodology for designing PTW casualty reduction programme and (d) a series of videos on how participating cities handled the project.

Significance/Contribution to the Field The comprehensive package of readily available tools offers a unique opportunity for follower cities toit from the mobility advantages offered by PTWs and to reduce safety related risks. 